\title{
Faglighed, frihed, lighed og fællesskab: to synspunkter
}

Marlene Harpsøe (MF) uddannelsesordfører, Dansk Folkeparti

Christine Antorini (MF) uddannelsesordfører, Socialdemokraterne

Regeringen kom i december 2010 med udspillet 'Faglighed og Frihed'. Fagligheden skal i følge udspillet øges ved at sætte tidligt ind overfor dårlige læsere, ved at opstille målbare del- og trinmål for elevernes læring og ved at udvikle en undervisning og en lærer-uddannelse, der i større grad er baseret på forskning og viden. Børn skal kunne læse ved udgangen af anden klasse, der skal indføres en 6 timers skoledag for de mindste, og de fremtidige ottende klasser skal kunne det samme som niende klasserne kan i dag. Herudover skal fagligheden øges ved at give prestigen tilbage til lærerfaget og ved at specialuddanne lærerne i højere grad. Friheden skal øges dels gennem at give skolerne større frihed til selv at eksperimentere sig frem til, hvordan de kan indfri deres mål. Der skal være større mulighed for undervisningsdifferentiering gennem holddannelse, oprettelse af talentklasser mv. Målopfyldelsen skal offentliggøres således, at det bliver muligt at sammenligne skolerne. Der lægges dermed op til resultatstyring af skolerne, frem for regelstyring. Herudover vil regeringen give 10 skoler særlig frihed til at eksperimentere med særlige måder at opnå deres mål på.

Regeringen berører også integrationsaspektet i udspillet især i forhold til 'ghettoskoler,' som skal underkastes særligt tilsyn, en styrkelse af undervisningen af dansk som andetsprog, og en incitamentsordning for private friskoler med få tosprogede børn til at påtage sig en større del af 'integrationsopgaven.' Integrationsaspektet berøres også i forbindelse med specialundervisning. 14 procent af alle elever modtager specialundervisning og udgifterne udgør 13 milliarder, svarende til 30 procent af udgifterne til folkeskolen. Regeringen ønsker at (re-) integrere elever fra special-klasser og special-skoler i de normale klasser, antagelig også med den hensigt at spare nogle af udgifterne til specialundervisning.

I forhold til dannelsen af eleverne som personer og medborgere understreger regeringen, at 'vi forsat [skal] udvikle danske elevers selvstændighed og refleksion, lyst og evne til at samarbejde, demokratiske forståelse og udsyn' (side 7). Der skal i denne forbindelse opstilles konkrete og målbare mål for elevens 'alsidige udvikling', f.eks. udviklingen af initiativrigdom, fællesskabsfølelse, hjælpsomhed, og tålmodighed med 'hverdagens faste rutiner'. Herudover vil regeringen have skolen til at lære eleverne 'innovation' og 'entreprenørskab'.

POLITIK havde oprindelig inviteret uddannelsesordførerne fra Dansk Folkeparti, Venstre, Socialdemokratiet og Enhedslisten til at komme med deres syn på 1) hvad skolens vigtigste funktioner er i dag, 2) hvor stor en grad af frihed de enkelte lærere og skoler bør have i deres arbejde, 3) hvordan det frie skolevalg påvirker muligheden for at sikre en god skolegang for alle, og 4) hvordan vi udvikler en skole i verdensklasse. POLITIKs invitationer blev delvist ofre for den uofficielt indledte valgkamp i foråret 2011, hvor hverken Venstre eller Enhedslisten så sig i stand at bidrage. Men heldigvis kan vi præsentere to interessante indlæg fra Marlene Harpsøe, Dansk Folkeparti, og Christine Antorini, Socialdemokraterne, der berører de ovennævnte spørgsmål og meget andet.

\section{Dansk Folkepartis uddannelsespolitik}

\author{
Marlene Harpsøe, MF Dansk Folkeparti
}

Debatten om folkeskolen har vist alle dage raset, det er der sådan set ikke så meget nyt i. Det er ikke spor mærkeligt, for langt de fleste danskere bliver direkte eller indirekte berørt af folkeskolen, og så er det klart og godt, at de fleste danskere også har en mening om folkeskolen. Men nogle gange skal man lige tage en dyb indånding og gå ned i det helt grundlæggende. Ofte handler debatten jo om enkelte brikker i det store puslespil, som folkeskolen er, og mit ærinde her er at forklare, hvordan Dansk Folkeparti ønsker, at det samlede billede skal se ud, når alle puslespillets brikker er lagt. 
Først og fremmest mener Dansk Folkeparti, at folkeskolens to vigtigste funktioner er: 1) At den enkelte elev opnår så høj faglighed, som det er muligt for den enkelte elev. 2) At den enkelte elev bliver klædt ordentligt på, så denne kan klare sig som voksen i samfundet. Herunder skal eleven få viden om danske værdier og dansk kultur, da det er en vigtig del af at kunne begå sig i samfundet, på arbejdspladsen og så videre. Disse to hovedfunktioner er lige vigtige, og det skal være muligt for folkeskolen at levere begge dele.

Spørgsmålet er så, hvordan man opnår dette. Først og fremmest må man sætte nogle klare mål, så lærere og forældre ved, hvad målet er. Dernæst skal man give lærerne redskaberne til at nå disse mål. Det kan være tiltag som elevplaner og kanoner, som nogle lærere måske har anset for at være et indgreb i deres undervisning, men som altså er en hjælp.

Elevplanerne skal bruges, så lærere og elever ved, hvor den enkelte elev kan blive bedre. For den enkelte elev skal undervises og udfordres på det niveau, som den enkelte elev nu er på. Vi svigter både de bogligt svage og de bogligt stærke, hvis alle elever bliver undervist ens. De bogligt svage kan ikke følge med, og de bogligt stærke keder sig.

Hvad kanonerne angår, er det i min optik en god ting, at lærere har noget at forholde sig til. Der har desværre været eksempler på lærere, der stort set blot har undervist i deres favoritforfattere, og det duer ikke.

Det er også vigtigt, at skolerne har fokus på danske værdier så som, at mænd og kvinder er ligeværdige. Og har skolerne ikke det, som vi så det på Holbergskolen i København, så er det landspolitikkernes pligt at gribe ind. For skolerne skal ikke tage særlige hensyn til grupper, der ønsker særbehandling, blot fordi det er det nemmeste at gøre. Netop dette har der desværre været en del eksempler på, og disse mennesker skal forstå, at i Danmark er det danske normer og værdier, der skal gælde. Hvis man forstår og tager disse til sig i folkeskolen, så vil man også have langt nemmere ved at begå sig på arbejdspladser og i andre sociale sammenhænge. Det gælder såvel indvandrere som børn af indvandrere.

I øjeblikket fylder debatten om folkeskoler og friskoler (private skoler) meget. Det er som om, man glemmer, at den danske friskoletradition er gammel, og at private skoler bestemt ikke er noget nyt. Det betyder dog ikke, at man ikke skal tage frygten for, at der opstår A- og B-hold blandt folkeskolerne alvorligt. Hvis alle ressourcestærke forældre tager deres børn ud af folkeskolen, så står vi naturligvis med et samfundsmæssigt problem. Men så vidt er det så langt fra kommet endnu. For at undgå dette skal vi sørge for, at folkeskolen har et niveau både fagligt og socialt, der gør folkeskolen til et attraktivt valg. Men vi skal holde fast i muligheden for, at forældre har mulighed for at vælge et alternativ til folkeskolen for deres børn, for denne valgmulighed er et gode.

Men såvel friskolerne, som folkeskolen, skal have et højt fagligt niveau, så vores børn fagligt bliver nogle af de dygtigste i verden. I Danmark har vi ikke store forekomster af guld eller olie, og derfor er det viden og kloge hoveder, vi skal leve af. Det er dem, der skal sikre, at Danmark også i fremtiden er et velfærdssamfund. Derfor skal vi lave nogle ting om, så fagligheden bliver styrket. Først og fremmest skal vi have gjort noget ved disciplinen eller manglen på samme i klasselokalerne. Det er selvsagt svært at undervise, hvis der er meget støj, og eleverne i $ø v$ rigt ikke har den mindste respekt for læreren. Desuden skal vi også sikre, at børnene føler sig som en del af et fællesskab. Det vil et tiltag som obligatorisk morgensang være med til. Der skal også meget mere idræt i folkeskolen, da eleverne bliver mere åbne for indlæring, desto mere motion de dyrker. Desuden skal musik og billedkunst styrkes blandt andet ved, at eleverne får karakterer i fagene, så de ikke bliver til „slappe af“-fag.

Det vigtigste er dog, at fagligheden bliver styrket. Her vil Dansk Folkeparti styrke læreruddannelsen. Der skal skabes respekt om lærerstanden. Det kræver bl.a. højere adgangskrav til læreruddannelsen og øgede krav til lærernes faglige og pædagogiske egenskaber. Undervisningens kvalitet skal derfor fortsat styrkes. Praktikperioder i folkeskolen skal til hver en tid indgå i undervisningen. Den enkelte lærerstuderende skal løbende evalueres og skal til enhver tid kunne præstere et tilfredsstillende fagligt niveau. Desuden skal lærerne gennemgå obligatorisk og relevant efteruddannelse, så vi sikrer, at lærerne hele tiden er opdateret og opfylder nye faglige og pædagogiske krav. 


\section{3 års uddannelse til alle}

\section{Christine Antorini, MF Socialdemokratiet}

Den dårlige nyhed er, at Danmark har mistet $\mathrm{i}$ titusindvis af arbejdspladser til ufaglærte. Det vil kun blive værre i årene fremover! Den gode nyhed er, at der samtidig vil blive brug for langt flere med uddannelse. Vel at mærke ikke bare med en universitetsuddannelse. Det danske arbejdsmarked er helt afhængigt af, at vi uddanner i hele viften af uddannelser. Fra håndværkere og social- og sundhedsassistenter til lærere, ingeniører og økonomer.

Hvad der ikke vil være et stort arbejdsmarked til, er ufaglærte. Vi har set konsekvenserne, da den økonomiske krise nåede Danmark. De ufaglærte blev fyret først, og ungdomsarbejdsløsheden er steget markant. Fælles for dem er, at hovedparten ikke har mere end folkeskolens afgangsprøve. Hvis de endda har fåt den.

Vi ved, det er afgørende at have både folkeskolen og en ungdomsuddannelse med videre i livet. Det skal vi tage konsekvensen af og hæve uddannelsespligten fra de nuværende 10 år til 13 års uddannelse til alle. Det kræver forandring af hele uddannelsesvejen fra førskole over folkeskole til ungdomsuddannelse. Ellers vil vi hægte endnu flere af med længere undervisningspligt. Lad os komme i gang med den forandring, så alle får lyst til at lære mere nu og hele livet. Folkeskolen skal forandres, så eleverne får flere timer på en mere spændende måde, der uddanner og almendanner meget forskellige børn, og der skal tænkes nye ungdomsuddannelsesveje, som den nye fleksuddannelse. ${ }^{1}$

Regeringen er optaget af større frihed til skolerne suppleret med mere fokus på de resultater, skolerne leverer. Som den nye undervisningsminister Troels Lund Poulsen har udtalt (JP 20.3), skal folkeskolen „udstille gode og dårlige skoler, dygtige og mindre dygtige børn“. Det har man gjort i både USA og England. Med faldende faglighed til følge, fordi der undervises i at dokumentere gode testresultater og ikke at lære mere. ${ }^{2}$

Vi skal i stedet gennemføre et uddannelsesmæssigt løft af samme dimensioner som socialreformen i 1930'erne og uddannelsesløftet i slutningen af 1960'erne og begyndelsen af 1970'erne. Her blev uddannelsespligten hævet fra 7 til 9 år, der blev indført den studieforberedende hf-uddannelse til voksne samt verdens første uddannelse til de faglige områder, nemlig de erhvervsfaglige grunduddannelser, EFG. Vi har brug for tilsvarende politiske initiativer, så der igen kommer gang i uddannelsesmobiliteten, der er gået i stå de sidste ti år, og folkeskolen spiller en nøglerolle.
Lad os derfor se på, hvad folkeskolens vigtigste funktioner er: Folkeskolens skal for det første at være med til at bryde den negative sociale arv, så alle børn har lige muligheder for og motivation til at lære mest muligt med de evner, de har. For det andet skal skolen udfordre eleverne, så de også møder det, de ikke vidste, de havde interesse og evner for. Med nysgerrighed, lyst til at gøre sig umage, mod til at møde modstand og kompetencer til at rumme de, der tænker og arbejder anderledes end dem selv på en konstruktiv måde.

Det er alt for uambitiøst at gøre det til et mål, at folkeskolen skal være i verdensklasse i fire discipliner, nemlig læsning, engelsk, matematik og naturfag, som regeringen har foreslået. Selvom vi legede med tanken om, at det lykkes, vil det så være verdens dygtigste unge, vi uddanner til fremtidens samfund? Nej vel? Det er langt mere komplekst, hvad man skal kunne i fremtiden end at være top-dygtig i fire enkeltstående discipliner. Der er ingen tvivl om, at vi skal være dygtige, og at læsning, matematik, engelsk og naturfag er kernefag. Ligesom fx historie og samfundsfag, som er røget helt ud af regeringens prioriteringsliste, også er kernefag. Og hvad med alle de håndværksmæssige, kropslige og kreative kompetencer? Evnen til at samarbejde og tænke nyt? De er også gledet ud af prioriteringen. På trods af, at vi skal have en folkeskole, der kan møde alle elever, hvor de er - og udvikle viften af kompetencer hos eleverne derfra.

Det er ikke svært at forstå, hvorfor rekrutteringen til de erhvervsrettede ungdomsuddannelser er blevet svær. For eleverne møder kun sporadisk denne uddannelsesvejs fag og kompetencer i folkeskolen. I folkeskolens ældste klassetrin er praktiske fag helt forsvundet, med mindre man starter på en særlig erhvervsklasselinje. Og det er pr definition nu blevet til de unge, der har svært ved skolen, selvom en erhvervs- og produktionslinje som et muligt valgspor i udskolingen ville være attraktiv for alle unge, også de dygtige. Samtidig er uddannelseskulturen blevet stadig mere boglig, frem for at udvikle en virkelighedsnær uddannelseskultur i et tæt samspil mellem praktik og teori hele vejen gennem folkeskolen.

Hvis det skal lykkes at gennemføre 13 års uddannelse til alle og få gang i uddannelsesmobiliteten igen, skal der sættes ind på fem hovedområder. For det første skal folkeskolen i et tæt samarbejde med daginstitutionerne styrke alle børns muligheder for at være skoleparate så hurtigt som muligt. Det betyder veluddannede pædagogisk ud- 
dannede medarbejdere i daginstitutionerne, der arbejder systematisk med de pædagogiske læreplaner, sprogscreening og sprogstimulering. Det forudsætter spredning af elever, så elever der af pædagogiske grunde vil lære mere ved at starte på en anden skole end deres distriktsskole bl.a. pga elevernes sociale sammensætning - flyttes dertil. Privatskoler skal også tage et socialt ansvar og sikre elevmangfoldighed. Når vi har statsfinansierede privatskoler i Danmark, er det kun rimeligt, at de bidrager til en grundskole for alle. Nogle gør det, men andre laver social sortering ved skoleporten ved at takke nej til elever, eller bede dem forlade skolen - og så skal folkeskolen samle op. Lad os indføre to takster til privatskoler, der afspejler de reelle uddannelsesopgaver, fx gennem en lavere grundtakst til elever uden særlige behov og en højere takst til elever, der har brug for specialundervisning.

For det andet skal eleverne have flere timer, så de lærer mere. Indfør to-lærerordninger i dansk og matematik fra 0. klasse. Obligatorisk lektiecafe. Læseløft til elever, der ikke har lært at læse efter 2. klasse. Max 24 elever i klasserne, så der er mere lærertid til eleverne og mulighed for at arbejde med hold efter fagligt niveau, motivation mv. Men hold fast i klassefællesskabet, da det løfter alle elever fagligt. Styrk forældresamarbejdet, så de bakker op om skolen og involverer sig i deres børns læring. De har ansvaret for, at børnene er veludhvilede, har lavet deres lektier, har sund madpakke med og ved, at de skal opføre sig ordentligt, fordi ro, orden og trivsel er afgørende for et godt læringsmiljø.

For det tredje skal der indføres langt flere helhedsskoler. Børnenes skoledag er i dag opdelt i en stadig kortere og meget boglig skoledag og en lang fritidshjemsdag. Skab en sammenhængende tid for eleverne med undervisning, leg og læring på kryds og tværs gennem hele dagen. I et tæt samarbejde mellem lærere og pædagoger. Med idræt, bevægelse og tilbud om sund morgenmad og frokost, så eleverne får energi til dagen, bruger deres krop til konkurrence og holdsport, som udover at være sjovt også stimulerer hjernen, så de er mere motiverede til at koncentrere sig om de boglige fag. Med praktisk-musiske fag og en virkelighedsnær undervisning, hvor der hele tiden arbejdes med teori-praktik i en vekselvirkning. Vi kender allerede denne skoleform, nemlig på de populære efterskoler, hvor eleverne strømmer til. Hvorfor? De er i et tæt socialt fællesskab. De tager folkeskolens afgangsprøve også i fag, hvor de havde mistet motivationen. De kan vælge linjer efter interesse lige fra idræt og musik til naturfag og IT. Og deres efterfølgende gennemførelse af en ungdomsuddannelse er høj!

For det fjerde skal vi sætte et ambitiøst udviklingsprogram i gang for IT-baserede undervisningsmetoder med udgangspunkt $i$, at alle elever og lærere har et digitalt pennalhus. Det giver samtidig mulighed for at arbejde med internationalisering på nye måder uafhængig af tid og sted. Brug de sociale medier og internettet til venskabsklasser, kultur- og samfundsforståelse og lære fremmedsprog både i skrift og tale. Det digitale pennalhus understøtter også hjælp til specialundervisning i klassen frem for de mange elever, der i dag ekskluderes til særlig hjælp uden for klassen. Lad elevernes digitale pennalhus indeholde standardprogrammer inden for $\mathrm{fx}$ tekst til tale, så ordblinde og elever med læseproblemer - og de elever der ganske enkelt lærer bedre ved at lytte - har de nødvendige digitale redskaber fra dag ét i deres egen klasse.

For det femte skal vi styrke forskning i pædagogik og didaktik samt styrke evalueringskulturen i folkeskolen. Det er godt med test som internt pædagogisk redskab. Det er nyttigt med elevplaner, der styrker både teamsamarbejdet blandt lærerne og dialogen mellem lærer, elev og forældre om fremadrettede mål. Og det er fint med kvalitetsrapporter, så kommunalbestyrelserne har et godt overblik over, hvordan det går på de enkelte skoler, og hvor de skal sætte ind overfor konkrete udfordringer. Men der er brug for en mere fremadrettet og lærende evalueringskultur. Dels gennem løbende metodeudvikling mellem professionshøjskolerne, universiteterne og direkte ud i de enkelte skoler. Dels gennem løbende evaluerings- og metodesparring på de enkelte skoler med udgangspunkt i deres egne evalueringsredskaber. Understøttet af fag- og ledelseskonsulenter, som det er gennemført med stor succes i Skotland i det såkaldte HMIE-evalueringsprogam. ${ }^{3}$ Tanken er at effektiv selvevaluering med kompetent ekstern sparring fører til konstante forbedringer.

Der er i den grad brug for både at tænke i nye løsninger nu for folkeskolen. Vel at mærke gennemført på en måde, så forandringerne bygger på den store viden, der er om, hvad der virker. Så vil vi kunne gennemføre det næste store uddannelsesspring med 13 års uddannelse til alle, så vi fortsat har en folkeskole og et uddannelsessystem, hvor alle har lige muligheder i en bred vifte af færdigheder og kompetencer.

\section{Noter}

1. Beslutningsforslag B 116 om fleksuddannelse for unge mellem 15 til 25 år, se http://www.ft.dk/samling/20091/beslutningsforslag/ B116/index.htm\#dok

2. Direktør professor Pasi Sahlberg, CIMO (Centre for International Mobility and Cooperation), Finland, se http://www.kl.dk/ImageVault/Images/id_46015/ImageVaultHandler.aspx

3. Se http://www.hmie.gov.uk/ 